\title{
Impact of Work-From-Home Human Resource Practices on the Performance of Online Teaching Faculty During Coronavirus Disease 2019
}

\author{
Huda Irshad ${ }^{1}$, Khawaja Muhammad Umar ${ }^{1}$, Mahmood Rehmani ${ }^{1 *}$, \\ Munnawar Naz Khokhar ${ }^{2}$, Naveed Anwar ${ }^{3}$, Ayaz Qaiser ${ }^{1}$ and Rana Tahir Naveed ${ }^{4}$ \\ ${ }^{1}$ Department of Business Administration, University of Sialkot, Sialkot, Pakistan, ${ }^{2}$ Department of Management Sciences, \\ COMSATS University, Islamabad, Pakistan, ${ }^{3}$ Department of Management Sciences, Shaheed Zulfiqar Ali Bhutto Institute of \\ Science and Technology, Larkana, Pakistan, ${ }^{4}$ Department of Economics and Business Administration, Division of \\ Management and Administrative Sciences, University of Education, Lahore, Pakistan
}

\section{OPEN ACCESS}

Edited by:

Tahir Islam,

Mohammad Ali Jinnah

University, Pakistan

Reviewed by:

Muhammad Mumtaz Khan,

Bahria University, Pakistan

Abdul Hameed Pitafi,

Sir Syed University of Engineering and Technology, Pakistan

*Correspondence:

Mahmood Rehman

mahmoodrehmani@gmail.com

Specialty section:

This article was submitted to

Organizational Psychology,

a section of the journal

Frontiers in Psychology

Received: 13 July 2021 Accepted: 10 September 2021

Published: 28 October 2021

Citation:

Irshad H, Umar KM, Rehmani M, Khokhar MN, Anwar N, Qaiser A and Naveed RT (2021) Impact of

Work-From-Home Human Resource

Practices on the Performance of

Online Teaching Faculty During

Coronavirus Disease 2019.

Front. Psychol. 12:740644.

doi: 10.3389/fpsyg.2021.740644
The purpose of this study was to investigate the impact of work-from-home (WFH) human resource (HR) practices on the performance of faculty under the drastic circumstances of coronavirus disease 2019 (COVID-19). The population of the study included faculty members of the higher education institutions in Sialkot, Pakistan. The study filled the gap of scarce literature on the impact of various HR practices by HR officials while working from home during lockdown observed to reduce the spread of COVID-19. Based on reinforcement theory, this article proves that there is a significant relationship between HR practices (including training, performance appraisal, career planning, employee participation, job definition, compensation, and selection) and faculty performance. It also proves that there is a strong positive relationship between the two variables. The findings of this study provide a blueprint to improve HR practices for high performance by faculty in the higher education sector during WFH settings.

Keywords: work-from-home, HR practices, online teaching faculty, employee performance, COVID-19

\section{INTRODUCTION}

Coronavirus disease 2019 (COVID-19) is a contagious respiratory and vascular disease caused by severe acute respiratory syndrome coronavirus 2 (SARS-CoV-2). While the pandemic has cost human lives, it has disrupted the economy and social aspects of life. According to the survey results of Marinoni et al. (2020), higher education institutions (HEIs) around the world are suffering due to the COVID-19 crisis in one way or the other. The regional analysis shows that Asia is at the brink of a growing risk of inequality among HEIs due to lack of access to technology and financial downfall. Qamar and Bawany (2021) state that Pakistan followed the footsteps of global educational institutions and switched to an online mode of learning, but this sudden change was not welcomed by all educationists and students. Rehman (2020) states the reason Pakistan was among the most affected countries as online education was an alien method for the people. The majority of the workforce consists of human capital and the need for hours stated a reformation in the workplace dynamics and that is how COVID-19 led to normalizing working from home. 
There is evidence that human resource (HR) practices positively affect employee performance and in the context of Pakistan studies (Bashir and Khattak, 2008; Shahzad et al., 2008; Bowra et al., 2012; Hameed et al., 2019, 2020; Khan et al., 2021b). Several HR practices can be linked with employee performance. Aycan et al. (2000) have called Pakistan an under-researched country in the context of HR management (HRM) practices as it is a developing country. During COVID-19, companies adopted the work-from-home (WFH) culture to survive, and it not only enhances the productivity of employees but also offers greater flexibility in work arrangements and creates better work-life balance (Dizaho et al., 2017).

This study attempts to fill the research gap in a developing country like Pakistan by finding a relationship among HR practices such as recruitment and selection, training and development, career management, and so on (Bashir and Khattak, 2008). Another study by Khalid et al. (2014) studied HR practices as career planning, performance appraisal, training, compensation, and employee participation concerning employee performance but research was limited to one city and public organizations. Any performance of an organization depends on the performance of its employees, which is measured by the HRM. The performance of an employee is what he/she does or does not do (Shahzadi et al., 2014; Sheikh et al., 2017; Islam et al., 2019). In the case of institutes, we turn employee performance into faculty performance as a variable. This study aims to analyze the link between seven HR practices and faculty performances in HEIs. Researchers have not conducted any study in institutes of Sialkot, Punjab, Pakistan to measure faculty performance during online classes. HR officials have implemented HR practices from home and faculty members have adhered to them working from home as well. The objective of the current study is to focus on the impact of WFH HR practices on faculty performance and whether these practices are linked with faculty performance or not. The results of the study significantly contribute to the previous literature and offer suggestions to HR managers for making the practices better in these difficult times.

\section{Literature Review and Hypothesis Development}

Armstrong (2006) defined HRM as a strategic and coherent approach to the management of the most valued assets of an organization, the people working there who individually and collectively contribute to the achievement of its objectives. The sudden transition of the education system to the online medium caused a stir. As much as students have faced troubles during learning, the digital rules and punctualities, so have the online teaching faculty found many challenges. Schools and colleges have principals and the level of management is slightly on a smaller scale than universities. Educational institutes may or may not have an integrated HR department but they perform practices such as planning, organizing, and managing the personnel. The higher management or the HR manager is responsible for setting the mission and the goals, motivating the employees, deciding on the best guidelines, and so on. The best HR practices include recruitment and selection, training and development, transparency, employee benefits, employee incentives, compensation and evaluations, compliance, and termination. As the foremost orders by the government strictly imposed social distancing, the challenge began to keep the organizations running smoothly, which meant a world without direct interactions.

The outbreak of COVID-19 has taught us that change is inevitable (Islam et al., 2020). The first preventative step suggested by WHO was social distancing. Every country closed schools, colleges, and universities. Moreover, the government canceled entrance tests, examinations, classes, and internships. It took students as well as the faculty by storm as adapting to the digitized education system was not easy. Change requires time; however, the pandemic caused the education sector in India to grow. Online education has proved to be a salvation for the students and teachers. They assigned work to students via the internet and delivered lectures through live video conferencing using applications like Zoom, Google meets Facebook, YouTube, and Skype. There are WhatsApp groups that help keep students, teachers, and even guardians connected and aware of the class schedules. Online learning is the best solution and is surely better than not getting to learn anything (Jena, 2020).

To better understand the impact of HR practices on faculty commitment, an empirical study has been conducted by Rahiman et al. (2018) to analyze demographic factors that have an impact on HR practices, the influence of explanatory variables on organizational commitment, the relationship between HR practices and organizational commitment, and, in addition, to suggest improvements in HR practices and commitment level. Quality of teaching staff and faculty commitment need to be restructured, which will, in turn, increase the quality of education and student satisfaction. It is only fair to say if the organization provides staff with the best training and environment, it directly affects the results of students. For stability and growth, every organization must have an integrated HR system. HR is the backbone of any organization and it helps carry out all organizational operations. HRM practices, namely, training and development, performance appraisals, teamwork, HR planning, compensations, safety, and health, help to enhance the performance of an employee by creating a psychological link with the organization that prevents him/her from leaving. Organizational commitment in higher education is necessary as teachers are not only facilitators for students but they thrive for their personal development as well.

Work-from-home has its pros and cons for teachers. If both the teacher and school go through it responsibly and both parties understand the conditions that occur, they can carry out WFH effectively. Even though the distance exists, it is important to maximize communications to avoid unnecessary issues (Purwanto et al., 2020). A successful performance management system helps in evaluating and improving both company and individual performance. The organization must not avoid performance evaluation, as it will result in poor business decisions. Employee recruitment and selection were being discouraged due to the pandemic especially in private organizations to avoid unnecessary spending. Managing employee performance was found to be challenging. Employees 
were unable to set realistic goals and even failed to achieve previously set goals. Monitoring performance was problematic and coordinating activities seemed too tedious. This affected compensation management, as the company no longer offered incentives. Some organizations got too far by asking their employees to take leave without pay and some were thinking about pay cuts. Private organizations suffered the most effects of the pandemic. When a company stops rewarding the employees, it destroys employee motivation. HRM practices are not immune to COVID-19. Employee recruitment and selection became more difficult in the time when employees voluntarily or involuntarily leave organizations. Employee training programs decreased and this challenging performance management, as monitoring from home is not easy. Jobs in public organizations are more secure than in private organizations and organizations should adopt electronic HRM (EHRM) and review HR policies (Mwita, 2020).

The COVID-19 pandemic has no duration and it forced rapid improvization and adoption of online teaching methods in educational institutes (Hou et al., 2021; Islam et al., 2021; Khan et al., 2021a). They used the approach based on synchronous and asynchronous learning. Synchronous learning is online or distance learning that is based on real-time interactions between students and facilitators. On the other hand, asynchronous learning occurs through online platforms without real-time interactions. Now that online education is taking place in the sector, online instructors need to take the role of facilitators and not just provide education but also enhance the learning of students. Online teaching methods, such as the opensource learning management system (LMS), used a free version of Zoom in different modules of Singapore. The adoption of LMS by HEIs to support student learning goes back to the late 1990s. They developed LMS platforms around three interrelated functions: (1) provision and organization of content, (2) course management including attendance, assessment, grade management, and announcements, and (3) communication tools. Online teaching requires three types of interrelated preparation. First, there is a process of selection, presentation, and grouping of resources. Second, there is planning required for each hour of online delivery and third, teaching online is much more tiring than classrooms. It involves managing multiple cues from students including engaging in voice-based discussions while observing and managing public and private chat rooms.

Lecturers working from home face many challenges as the virtual classrooms introduced a new form of encounter with family members especially children or pets. Online-only blended learning is still an unusual form of the classroom. The purpose of this transition is to provide a platform equally for every student in any geographical location and even if he or she is exercising quarantine. Online makes it difficult to connect for students. The shift to online teaching forms the role of the instructor from teacher to guide, facilitator, coordinator, challenger, stimulator, encourager, or conductor. Students require more online selfdiscipline. COVID-19 is forcing deeper adoption of the LMS system and the development of a curation-oriented learning paradigm. For module development, the process of curation takes two forms: curating content to support learning outcomes and curating student experiences. The latter is important as it reflects a balance between students and lecturers. In online encounters, those involved must work harder to read non-verbal or social cues including gestures, expressions and tone, and pitch of the voice. Undoubtedly, the transition to online learning has been very tiring. As nothing can replace proximate learning, the modules stated that students should be encouraged to discuss and engage in sessions (Bryson and Andres, 2020).

According to the reinforcement theory, behavior is a function of its consequence. The consequences that immediately follow behavior and increase the probability to repeat a behavior are reinforcers. The biggest $\mathrm{HR}$ challenges of the year 2020 were focusing on employees and communicating often. It is human psychology when efforts go unappreciated the person is automatically demoralized, which results in the prevention of further out-of-the-mile hard work. Getting used to the online education transition has been reckless to the faculty and they deserve sufficient motivation even if it is a single appreciation email. According to Skinner (1958), people will most likely engage in desired behaviors if they receive a reward for doing so. Managers can easily influence employee behaviors by using positive reinforcers for actions that help the organization achieve its goal, which in this case is maximum faculty performance. This will equilibrate the effects of HR practices from home on online teaching faculty.

\section{Relationship Between HR Practices and Online Teaching Faculty Performance}

Teachers and lecturers can deliver lectures through technology. WFH provides flexibility in completing work. This cuts down transportation costs and saves time. Even if the factor of stress occurs, the faculty can easily find comfort in the atmosphere of his/her home, and this way productivity increases. With this comes job satisfaction, which certainly increases loyalty to the organization for faculty. On the other hand, loss of work motivation working from home can severely affect the performance of faculty. Moreover, due to the daily increased use of the internet and electricity, the individual has to bear the cost of working from home (Purwanto et al., 2020). Employers, as well as HR managers, have been compelled to redefine HR roles and bring about best practices. HR plays an important role to bring the concept of "people connect" to light and create a bond with the people at the organization. It is up to HR to make the home of an employee a substitute for the workplace. The relative success of WFH is one of the achievements worldwide in this disaster. HR is responsible for motivating, inspiring, training, and developing the people, normalizing usage of technology to efficiently work and manage work relationships according to the changing scenarios (Kaushik and Guleria, 2020). There is research evidence that a strong positive relationship exists between HR practices and employee performance as it can be seen in Figure 1 (Bashir and Khattak, 2008; Shahzad et al., 2008; Bowra et al., 2012; Khalid et al., 2014). Each construct including seven HR practices and faculty performance has been defined in Table 1. Hence, we hypothesize the following:

$\mathrm{H1}$ : There is a significant positive effect of WFH HR practices on the performance of online teaching faculty. 


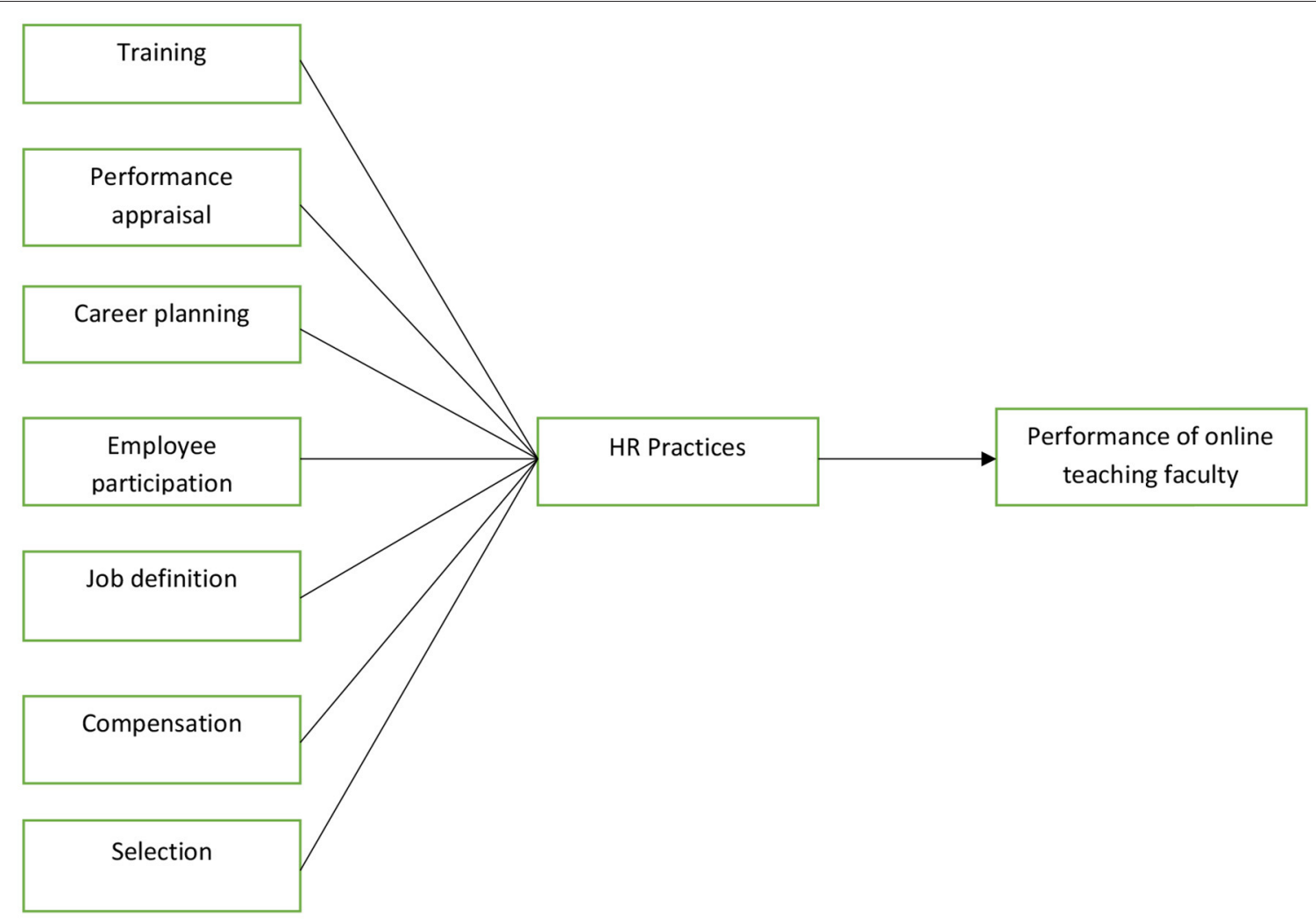

FIGURE 1 | Theoretical framework.

TABLE 1 | Constructs defined.

Training

Performance appraisal

Career planning

Employee participation

Job definition

Compensation

Selection

Faculty performance
"A learning process where people learn knowledge, attitudes, concept, and skills to achieve organizational goals" (Ripley, 2002)

"The process by which superiors evaluate the performance of employees for determining training needs or promotions" (Grote and Grote, 2011)

"Process of targeting career development and implementation of strategies, self-assessment, analysis and evaluation of results" (Antoniu, 2010)

"Participation of non-managerial employees in decision making" (Kapur, 2018)

"A list of job duties, responsibilities, reporting relationships, working conditions, and supervisory responsibilities" (Valenzi and Dessler, 1978)

"A combination of non-financial and financial remuneration given to employees in return for performance by the employer as salary, bonus etc." (Osibanjo et al., 2014)

"The process of choosing the most suitable person from a pool of candidates, within or outside the organization" (Koontz, 2010)

"The degree to which a faculty member has achieved goals of teaching or service at the organization" (Kurz et al., 1989)

\section{Faculty Performance}

Performance is what an organization hires an employee for. It is the outcome of a task for an individual (Shahzadi et al., 2014). Employee or job performance is related to organizational goals and it is the result of the work of an employee. The aggregated value to an organization of the set of behaviors that employees contribute to fulfilling organizational goals is employee performance (Borman and Motowidlo, 1993). In educational institutes, employees are called faculty members and so the dependent variable of this study is faculty performance. Faculty performance deals with outcomes and accomplishments at work (Anitha, 2014). Moreover, the behavior of an employee is important for defining his/her performance (Aguinis, 2009).

\section{HR Practices}

Effective HR management practices can be the main factor for the success of a firm (Stavrou-Costea, 2005). HR practices help to improve business performance including employee productivity (Lee and Lee, 2007). HR also provides an orientation to the employees allowing them to understand the organizational culture, which encourages performance. For faculty working from home, HR proves to be a ray of light. HR practices 
significantly affect academic staff performance (Hashim et al., 2017; Shahzad et al., 2020). Many researchers have studied the relationship between employee performance and HR practices but they confined the study to developed countries (Aycan et al., 2000). Few pieces of research in Pakistan found a significant relation between HR practices and employee performance but the study was limited to public sector universities (Shahzad et al., 2008).

\section{Training}

Firms can provide training and development to employees to increase their performance levels. An employee is satisfied only when he/she feels eligible for performing his/her job through training programs (Elnaga and Imran, 2013). Training allows employees to have a better understanding of workplace ethics and their responsibilities. This practice is considered best as it brings about the desired change in employee performance (Delaney and Huselid, 1996). May it be information or new skills training impacts employee performance, we formulate the following hypothesis to find out whether the HR practice training and faculty performance has a relationship.

$\mathrm{H} 2$ : There is a significant relationship between training and the performance of online teaching faculty.

\section{Performance Appraisal}

The appraisal of employees may be performance-based and attendance-based. The HR monitors and evaluates performance or attendance by using ranking scales. Appraisals are the process of evaluating how employees perform at work and the responsibilities assigned to them in comparison to the objectives that have been set for them. According to the job descriptions, HR measures the present performance concerning the expected performance. If the performance needs improvement, HR manages it. Appraisal-based information is helpful in the training process. An important aspect of appraisal is employee motivation, which ensures better performance (Singh, 2004). We can hypothesize that,

H3: There is a significant relationship between performance appraisal and the performance of online teaching faculty.

\section{Career Planning}

Selecting career goals and paths to these goals allows employees to understand personal and organizational goals with clarity. This encourages employees to plan accordingly on how to reach their full capacity. As a result, the employee finds motivation and satisfaction, which enhances performance (Beardwell and Claydon, 2007). There is a relationship between career planning and performance, we hypothesize the following to test this.

H4: There is a significant relationship between career planning and the performance of online teaching faculty.

\section{Employee Participation}

Participation has statistically significant effects on the performance, satisfaction, and productivity of an employee (Wagner, 1994). Maslow's theory of motivation states clearly that the need to earn money is not the only motive but being involved in decision-making and problem-solving provides a greater sense of belonging and motivates to perform better under the job description. We develop a hypothesis to find out the relationship between the HR practice of employee participation and faculty performance.

H5: There is a significant relationship between employee participation and the performance of online teaching faculty.

\section{Job Definition}

If employees are involved in defining their job and are wellacquainted with the requirements, it increases their motivation level. Defining a job means forming a job description and job specification. An overview of duties, responsibilities, and functions of a specific job is the job description. The qualifications and skills required for that job are the job specifications. If the organization confines job definition to the set standards, it prevents the employee to perform at his/her full potential (Singh, 2004). During online teaching, job definition helps to enhance the performance of faculty or not we formulate the following hypotheses to evaluate this.

H6: There is a significant relationship between job definition and the performance of online teaching faculty.

\section{Compensation}

Incentives and bonuses comprise compensation and benefits for the employees. As each HR practice is somewhat connected, performance appraisal backs up the compensation. As the supporting theory suggests reinforcing employee performance has fruitful results. Incentive-based compensation has an impact on firm performance (Milkovich et al., 1996). Compensation can help in maintaining the productivity of the employees or else they tend to leave the organization searching for better opportunities where they are rewarded better (Darma and Supriyanto, 2017).

H7: There is a significant relationship between compensation and performance of online teaching faculty.

\section{Selection}

The backbone of HR practices in recruitment is selection. Out of a pool of candidates through interviews, employees are hired. The better the selection system, the higher the expectations of performance are. It falls upon the interviewer to select carefully the right person for the respective job or it can cost the organization a lot of time and resources. Firm performance relates to selection positively (Terpstra and Rozell, 1993). To confirm the relationship of selection with the performance of online teaching faculty, we form the following hypotheses.

$\mathrm{H} 8$ : There is a significant relationship between selection and performance of online teaching faculty.

\section{MATERIALS AND METHODS}

Higher education institutes in Sialkot, Punjab, Pakistan, were selected to examine the relationship between HR practices and 
faculty performance. Through Higher Education Commission (HEC) Pakistan's website, we found out there were only four such institutes in Sialkot. The total population consisted of 709 faculty members employed at the institutes. The survey questionnaire method was used to collect data and through emails, the target respondents were reached out. The questionnaire consisted of instruments formed by Singh (2004) to measure HR practices. To measure the performance of online teaching faculty, the scale developed by Pradhan and Jena (2017) is used. Due to the strict policies of lockdown, we were not allowed to visit the universities, so an online survey aided us favorably. We used convenience sampling to overcome the COVID-19 constraints and 179 responses were collected in 3 months.

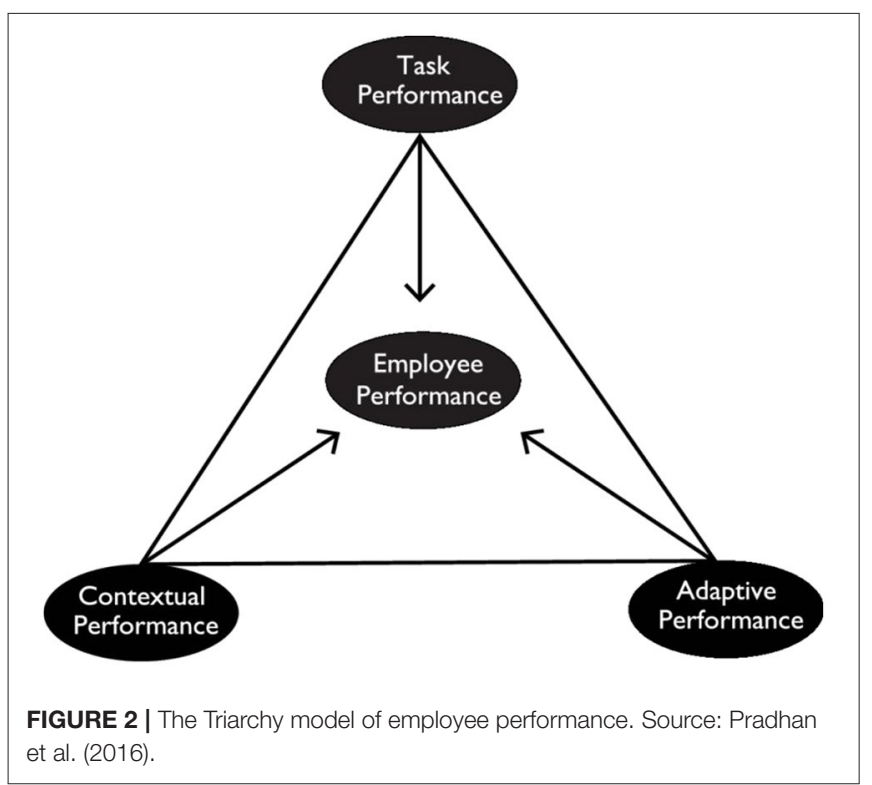

\section{Independent Variable}

Human resource practices consist of seven indicators: Training, performance appraisal, career planning, employee participation, job definition, compensation, and selection. We used the Likert scale to measure each indicator. Each scale was a five-point scale with " 1 " = strongly disagree to " 5 " = strongly agree. The

TABLE 3 | Reliability statistics.

\begin{tabular}{lcc}
\hline Variables & Cronbach's alpha & N of Items \\
\hline Training & 0.867 & 6 \\
Performance appraisal & 0.911 & 7 \\
Career planning & 0.888 & 7 \\
Employee participation & 0.802 & 3 \\
Job definition & 0.815 & 4 \\
Compensation & 0.800 & 5 \\
Selection & 0.781 & 4 \\
HR practices & 0.966 & 36 \\
Faculty performance & 0.940 & 22 \\
\hline
\end{tabular}

TABLE 4 | Descriptive statistics.

\begin{tabular}{llll}
\hline & Mean & SD & N \\
\hline Faculty performance & 3.9010 & 0.70560 & 179 \\
Training & 3.7225 & 0.83836 & 179 \\
Performance appraisal & 3.7749 & 0.84636 & 179 \\
Career planning & 3.6824 & 0.80891 & 179 \\
Employee participation & 3.7002 & 0.90711 & 179 \\
Job definition & 3.7318 & 0.84760 & 179 \\
Compensation & 3.6335 & 0.82120 & 179 \\
Selection & 3.6103 & 0.85995 & 179 \\
\hline
\end{tabular}

TABLE 2 | Descriptive analysis.

\begin{tabular}{|c|c|c|c|c|}
\hline S.no & Demographic variable & Demographic characteristics & Frequency & Percentage \\
\hline \multirow[t]{4}{*}{1} & Age & & & \\
\hline & & $20-30$ & 129 & 72.1 \\
\hline & & $40-50$ & 7 & 3.9 \\
\hline & & $50-60$ & 6 & 3.4 \\
\hline \multirow[t]{4}{*}{2} & Gender & & & \\
\hline & & Female & 140 & 78.2 \\
\hline & & Male & 39 & 21.8 \\
\hline & & Total & 179 & 100.0 \\
\hline \multirow[t]{2}{*}{3} & Work Experience & & & \\
\hline & & Total & 179 & 100.0 \\
\hline
\end{tabular}


respondents were asked to indicate their opinion by the fivescale. In the questionnaire, we wrote the scale as follows: " 5 " $=$ strongly agree, " 4 " = agree, “ 3 " = neutral, " 2 " = disagree, and " 1 " = strongly disagree. This helped respondents understand what it would mean exactly to choose the different rating scales. Training has six items; respondents chose the scale to denote the need for training. Performance appraisal has seven items; we asked respondents to indicate the extent to which performance is evaluated. Employee participation has three items; we expected respondents to express the level of liberty to speak in managerial decisions. Job definition has four items; we asked respondents to indicate the extent of the definition of a job. Compensation has five items; we required respondents to choose the scale expressing the relation of performance with compensation. The selection has four items; we asked respondents to indicate the importance of selection tools. HR practices variable has 36 indicators.

\section{Dependent Variable}

We measured faculty performance using the tool for employee performance (Figure 2). It consists of the triarchy model of employee performance suggested by Pradhan and Jena (2017). Task performance, adaptive performance, and contextual performance comprise employee performance. Faculty performance has 22 indicators.

\section{Data Collection and Analysis}

We have used International Business Machines Statistical Package for Social Sciences (IBM SPSS) 25.0 (x64) for conducting descriptive, regression, and correlation analysis. The demographic factors include age, gender, and work experience. The following tables provide the statistics of demographics:

Table 2 shows the majority of respondents are from the age bracket of $20-30$ (129), which is $72.1 \%$ of the data. Only 36 respondents are of the ages $30-40$ and this is $20.1 \%$ of the sample.

TABLE 5 | Correlation analysis.

\begin{tabular}{|c|c|c|c|c|c|c|c|c|c|}
\hline & & Training & $\begin{array}{c}\text { Performance } \\
\text { appraisal }\end{array}$ & $\begin{array}{l}\text { Career } \\
\text { planning }\end{array}$ & $\begin{array}{c}\text { Employee } \\
\text { participation }\end{array}$ & $\begin{array}{c}\text { Job } \\
\text { definition }\end{array}$ & Compensation & Selection & $\begin{array}{c}\text { Faculty } \\
\text { performance }\end{array}$ \\
\hline \multirow[t]{3}{*}{ Training } & $\begin{array}{l}\text { Pearson } \\
\text { Correlation }\end{array}$ & 1 & $0.786^{\star \star}$ & $0.667^{\star \star}$ & $0.554^{\star *}$ & $0.458^{\star \star}$ & $0.535^{\star \star}$ & $0.583^{\star \star}$ & $0.461^{\star \star}$ \\
\hline & Sig. (2-tailed) & & 0.000 & 0.000 & 0.000 & 0.000 & 0.000 & 0.000 & 0.000 \\
\hline & $N$ & 179 & 179 & 179 & 179 & 179 & 179 & 179 & 179 \\
\hline \multirow[t]{3}{*}{$\begin{array}{l}\text { Performance } \\
\text { appraisal }\end{array}$} & $\begin{array}{l}\text { Pearson } \\
\text { Correlation }\end{array}$ & $0.786^{\star \star}$ & 1 & $0.791^{\star *}$ & $0.666^{\star \star}$ & $0.665^{\star \star}$ & $0.664^{\star \star}$ & $0.746^{\star \star}$ & $0.513^{\star \star}$ \\
\hline & Sig. (2-tailed) & 0.000 & & 0.000 & 0.000 & 0.000 & 0.000 & 0.000 & 0.000 \\
\hline & N & 179 & 179 & 179 & 179 & 179 & 179 & 179 & 179 \\
\hline \multirow[t]{3}{*}{ Career planning } & $\begin{array}{l}\text { Pearson } \\
\text { Correlation }\end{array}$ & $0.667^{\star \star}$ & $0.791^{\star *}$ & 1 & $0.758^{\star \star}$ & $0.700^{\star *}$ & $0.711^{\star \star}$ & $0.776^{\star \star}$ & $0.554^{\star \star}$ \\
\hline & Sig. (2-tailed) & 0.000 & 0.000 & & 0.000 & 0.000 & 0.000 & 0.000 & 0.000 \\
\hline & $N$ & 179 & 179 & 179 & 179 & 179 & 179 & 179 & 179 \\
\hline & $N$ & 179 & 179 & 179 & 179 & 179 & 179 & 179 & 179 \\
\hline \multirow[t]{3}{*}{ Job definition } & $\begin{array}{l}\text { Pearson } \\
\text { Correlation }\end{array}$ & $0.458^{\star \star}$ & $0.665^{\star \star}$ & $0.700^{\star *}$ & $0.728^{\star \star}$ & 1 & $0.703^{\star \star}$ & $0.707^{\star \star}$ & $0.407^{\star \star}$ \\
\hline & Sig. (2-tailed) & 0.000 & 0.000 & 0.000 & 0.000 & & 0.000 & 0.000 & 0.000 \\
\hline & $N$ & 179 & 179 & 179 & 179 & 179 & 179 & 179 & 179 \\
\hline \multirow[t]{3}{*}{ Compensation } & $\begin{array}{l}\text { Pearson } \\
\text { Correlation }\end{array}$ & $0.535^{\star \star}$ & $0.664^{* *}$ & $0.711^{\star *}$ & $0.751^{\star \star}$ & $0.703^{\star \star}$ & 1 & $0.756^{\star \star}$ & $0.466^{\star \star}$ \\
\hline & Sig. (2-tailed) & 0.000 & 0.000 & 0.000 & 0.000 & 0.000 & & 0.000 & 0.000 \\
\hline & $N$ & 179 & 179 & 179 & 179 & 179 & 179 & 179 & 179 \\
\hline Selection & $\begin{array}{l}\text { Pearson } \\
\text { Correlation }\end{array}$ & $0.583^{\star \star}$ & $0.746^{\star \star}$ & $0.776^{\star \star}$ & $0.741^{\star \star}$ & $0.707^{\star \star}$ & $0.756^{\star \star}$ & 1 & $0.514^{\star \star}$ \\
\hline
\end{tabular}

**. Correlation is significant at the 0.01 level (2-tailed). 
TABLE 6 | Coefficients ${ }^{a}$

\begin{tabular}{|c|c|c|c|c|c|c|}
\hline Model & B & \multicolumn{2}{|c|}{ Unstandardized Coefficients } & Standardized Coefficients & $\mathbf{t}$ & Sig. \\
\hline & HR Practices & 0.555 & 0.060 & 0.569 & 9.203 & 0.000 \\
\hline
\end{tabular}

${ }^{a}$ Dependent Variable: Faculty performance.

TABLE 7 | Hypothesis decisions.

H1: There is a significant positive effect of work-from-home human resource practices on the performance of online teaching faculty

$\mathrm{H} 2$ : There is a significant relationship between training and performance of online teaching faculty

H3: There is a significant relationship between performance appraisal and the performance of online teaching faculty

Accepted

$\mathrm{H} 4$ : There is a significant relationship between career planning and the performance of online teaching faculty

Accepted

H5: There is a significant relationship between employee participation and the performance of online teaching faculty

Accepted

H6: There is a significant relationship between job definition and performance of online teaching faculty

$\mathrm{H7}$ : There is a significant relationship between compensation and performance of online teaching faculty

Accepted

Accepted

H8: There is a significant relationship between selection and performance of online teaching faculty

Accepted

Accepted

Remaining respondents belong to the ages $40-50$ (3.9\%), 50-60 (3.4\%), or 60 and above $(0.6 \%)$. The majority of the respondents are female. The received responses from women are $78.2 \%(140)$, while the remaining $21.8 \%$ (39) are from men. There are 130 respondents out of 179 having work experience of fewer than 5 years. This counts for $72.6 \%$ of the data. Only 40 respondents have $5-15$ years of experience (22.3\%), while the remaining $5 \%$ have 15 years or more of work experience.

The reliability analysis deals with Cronbach's alpha and according to the general rule of thumb, it should be 0.70 or above. Table 3 shows the value of Cronbach's alpha for HR practices collectively and each indicator. HR practices $(\alpha=0.966)$, training ( $\alpha=0.867)$, performance appraisal $(\alpha=0.911)$, career planning ( $\alpha=0.888$ ), employee participation $(\alpha=0.802)$, job definition ( $\alpha=0.815)$, compensation ( $\alpha=0.800)$, selection $(\alpha=0.781)$, and faculty performance $(\alpha=0.940)$. The variables have high reliability and are acceptable for further analysis.

The following table sets out the descriptive statistics in terms of means and SDs. The values of SD in Table 4 are higher than the mean of all variables. This means the variation in data is in a large range.

The table of correlation shows a significance at 0.01 level for each variable, which makes us accept the hypothesis. The values are statistically significant. We accept that there is a relationship between HR practices and the performance of online teaching faculty.

Based on the correlation coefficient, we conclude that there is a strong positive impact of WFH HR practices on the performance of online teaching faculty. A positive correlation means there is a direct relationship between the two variables. If the independent variable increases, the dependent variable will increase too.

\section{RESULTS, DISCUSSIONS, AND CONCLUSIONS}

The findings of this study are in communion with existing literature that there is a positive relationship between HR practices and performance (Shahzad et al., 2008; Akhter et al., 2013; Ali et al., 2020). Based on correlation results, we accept $\mathrm{H} 2, \mathrm{H} 3, \mathrm{H} 4, \mathrm{H} 5, \mathrm{H} 6, \mathrm{H} 7$, and $\mathrm{H} 8$ suggesting that training, performance appraisal, career planning, employee participation, job definition, compensation, and selection, respectively, have a statistically significant relationship with faculty performance in HEIs at Sialkot. Furthermore, the correlation coefficient shows the existence of a strong positive relationship between all HR practices understudy and faculty performance. This fills the literature gap by studying various $\mathrm{HR}$ practices in the educational context during COVID-19. As employee performance is measured by the $\mathrm{HR}$ management of any organization, so there is not much room for biases in the selfreported data of the study. As evident from Tables 5, 6, the HR practices individually and as a whole have a strong relationship $(p \leq 0.01)$ with faculty performance. So, we accept $\mathrm{H} 1$ and fulfill the objective of this study to find the impact of HR practices on the performance of online teaching faculty. Table 7 consists of each hypothesis and its decision.

\section{Research Implications}

Although correlation analysis shows significant values, HR managers should encourage employee participation in decisionmaking and make idea-sharing comfortable. This will in turn instill modern HR practices and improve their understanding of these practices. The findings of the study prove how the HR of an organization can result in a competitive advantage. A highperforming employee can lead to organizational success. Given the conditions of WFH, it is best to revise compensation plans as Pakistan has a low GDP and it is essential to prevent largescale unemployment. It is not only a pandemic but a new reality for organizations and the only way is to strategically comply. In short, the findings of this study provide a blueprint to enhance HR practices for higher employee performance.

\section{Limitations and Suggestions}

The research context is limited to HEIs in Sialkot and due to limited reachability sample size could not be large. For 
future research, more cities should be included in the target population to test the linkages between $\mathrm{HR}$ practices and faculty performance. Moreover, the addition of a mediator as transformational leadership might help explore other factors that strengthen the relationship under study. Data collection through online surveys may have caused a hurdle for respondents who lacked accessibility, so future research should use personally administered questionnaires and interviews as well. The majority of the respondents were females (78.2\%) while the data collection was intended to show results from both genders. Finally, respondents should be from both public and private universities to expand the study. Improving the learning outcomes and quality of teachers is necessary and not just because of the pandemic. In education, technology is the new medium to ensure the literacy rate getting better in Pakistan.

\section{REFERENCES}

Aguinis, H. (2009). "An expanded view of performance management," in Performance Management: Putting Research Into Practice, ed J. W. Smither (Manuel London; San Francisco, CA: Jossey-Bass A Wiley Imprint), 1-43.

Akhter, M., Siddique, M., and Alam, A. (2013). HRM practices and its impact on employee performance: a study of the cement industry in Bangladesh. Glob. Disclos. Econ. Bus. 2:125. doi: 10.18034/gdeb.v2i2.187

Ali, A., Wang, H., Soomro, M. A., and Islam, T. (2020). Shared leadership and team creativity: construction industry perspective. J. Construct. Eng. Manage. 146:04020122. doi: 10.1061/(ASCE)CO.1943-7862.0001920

Anitha, J. (2014). Determinants of employee engagement and their impact on employee performance. Int. J. Prod. Perform. Manage. 63, 308-323. doi: 10.1108/IJPPM-01-2013-0008

Antoniu, E. (2010). Career planning process and its role in human resource development. Ann. Univ. Petroşani Econ. 10, 13-22.

Armstrong, M. (2006). A Handbook of Human Resource Management Practice. London \& Sterling: Kogan Page Publishers.

Aycan, Z., Kanungo, R., Mendonca, M., Yu, K., Deller, J., Stahl, G., et al. (2000). Impact of culture on human resource management practices: a 10-country comparison. Appl. Psychol. 49, 192-221. doi: 10.1111/1464-0597.00010

Bashir, S., and Khattak, H. R. (2008). Impact of selected HR practices on perceived employee performance, a study of Public Sector Employees in Pakistan. Eur. J. Soc. Sci. 5, 243-252.

Beardwell, J., and Claydon, T. (2007). Human Resource Management: A Contemporary Approach. New York, NY: Pearson Education.

Borman, W. C., and Motowidlo, S. J., (1993). "Expanding the criterion domain to include elements of contextual performance," in Personnel Selection in Organizations, eds N. Schmitt and W. C. Borman (San Francisco, CA: JosseyBass.), 71-98.

Bowra, Z. A., Sharif, B., Saeed, A., and Niazi, M. K. (2012). Impact of human resource practices on employee perceived performance in banking sector of Pakistan. Afr. J. Bus. Manage. 6, 323-332. doi: 10.5897/AJBM11.2312

Bryson, J. R., and Andres, L. (2020). Covid-19 and rapid adoption and improvisation of online teaching: curating resources for extensive versus intensive online learning experiences. J. Geogr. High. Educ. 44, 608-623. doi: $10.1080 / 03098265.2020 .1807478$

Darma, P. S., and Supriyanto, A. S. (2017). The effect of compensation on satisfaction and employee performance. Manage. Econ. J. 1, 12-21. doi: $10.18860 /$ mec-j.vli1.4524

Delaney, J. T., and Huselid, M. A. (1996). The impact of human resource management practices on perceptions of organizational performance. Acad. Manage. J. 39, 949-969. doi: 10.2307/256718

Dizaho, E. K., Salleh, R., and Abdullah, A. (2017). Achieveing work life balance through flexible work schedules and arrangements. Glob. Bus. Manage. Res. 9.

\section{DATA AVAILABILITY STATEMENT}

The original contributions presented in the study are included in the article/supplementary material, further inquiries can be directed to the corresponding author/s.

\section{AUTHOR CONTRIBUTIONS}

HI conceptualized the research topic. KU helped with the data collection. The final draft was made by HI. All this is done under the supervision of the very informative and supportive MR. Visualization and validation were done by NA. Proofreading has been done by MK while AQ and RN have helped make revisions in the manuscript. All authors contributed to the article and approved the submitted version.

Elnaga, A., and Imran, A. (2013). The effect of training on employee performance. Eur. J. Bus. Manage. 5, 137-147.

Grote, D., and Grote, R. C. (2011). How to Be Good at Performance Appraisals: Simple, Effective, Done Right. Harvard Business Press.

Hameed, Z., Khan, I. U., Islam, T., Sheikh, Z., and Khan, S. U. (2019). Corporate social responsibility and employee pro-environmental behaviors. South Asian J. Bus. Stud. 8, 246-265. doi: 10.1108/SAJBS-10-2018-0117

Hameed, Z., Khan, I. U., Islam, T., Sheikh, Z., and Naeem, R. M. (2020). Do green HRM practices influence employees' environmental performance? Int. J. Manpow. 41, 1061-1079. doi: 10.1108/IJM-08-2019-0407

Hashim, M., Rafi, S., Kazmi, S. S. A., Ullah, M., and Kee, D. M. H. (2017). Impact of human resource practices on perceived performance: a study of teaching faculty in private universities of Peshawar, Pakistan. City Univ. Res. J. 120-129.

Hou, Y., Khokhar, M., Khan, M., Islam, T., and Haider, I. (2021). Put safety first: exploring the role of health and safety practices in improving the performance of SMEs. SAGE Open 11, 1-8. doi: 10.1177/2158244021103 2173

Islam, T., Hu, M., Pitafi, H., Zafer, A. U., Sheikh, Z., Mubarik, M. S., et al. (2021). Why do citizens engage in government social media accounts during COVID-19 pandemic? A comparative study. Telemat. Informat. 62:101619. doi: 10.1016/j.tele.2021.101619

Islam, T., Islam, R., Pitafi, A. H., Xiaobei, L., Rehmani, M., Irfan, M., et al. (2019). The impact of corporate social responsibility on customer loyalty: the mediating role of corporate reputation, customer satisfaction, and trust. Sustain. Prod. Consumpt. 25, 123-135. doi: 10.1016/j.spc.2020. 07.019

Islam, T., Pitafi, H., Wang, Y., Aryaa, V., Mubarik, S., Akhater, N., et al. (2020). Panic buying in the COVID-19 pandemic: a multi-country examination. $J$. Retail. Consum. Serv. 59:102357. doi: 10.1016/j.jretconser.2020.102357

Jena, P. K. (2020). Impact of pandemic COVID-19 on education in India. Int. J. Curr. Res. 12, 12582-12586. doi: 10.31235/osf.io/2kasu

Kapur, R. (2018). Employee Participation in Management. Available online at: https://www. researchgate. net/publication/338679820_Employee_Participation_in_Management

Kaushik, M., and Guleria, N. (2020). The impact of pandemic COVID-19 in workplace. Eur. J. Bus. Manage. 12, 1-10.

Khalid, M., Rehman, C. A., and Ilyas, D. (2014). HRM Practices and employee performance in public sector organizations in Pakistan: an empirical study. Int. J. Manage. Sci. Bus. Res. 3, 69-77. Available online at: https://www.academia. edu/28380607/HRM_Practices_and_Employee_Performance_in_Public_ Sector_Organizations_in_Pakistan_An_Empirical_study?source=swp_share

Khan, M. M., Mubarik, M. S., Ahmed, S. S., Islam, T., Khan, E., Rehman, A., et al. (2021a). My meaning is my engagement: exploring the mediating role of meaning between servant leadership and work engagement. Leadersh. Organ. Dev. J. 42, 926-941. doi: 10.1108/LODJ-08-2020-0320 
Khan, M. M., Mubarik, M. S., Islam, T., Rehman, A., Ahmed, S. S., Khan, E., et al. (2021b). How servant leadership triggers innovative work behavior: exploring the sequential mediating role of psychological empowerment and job crafting. Eur. J. Innov. Manage. doi: 10.1108/EJIM-09-2020-0367. [Epub ahead of print].

Koontz, H. (2010). Essentials of Management. Chennai: Tata McGrawHill Education.

Kurz, R. S., Mueller, J. J., Gibbons, J. L., and DiCataldo, F. (1989). Faculty performance. J. High. Educ. 60, 43-58. doi: 10.1080/00221546.1989.1177 8823

Lee, F.-H., and Lee, F.-Z. (2007). "The relationships between HRM practices, leadership style, competitive strategy and business performance in Taiwanese steel industry," in Paper Presented at the Proceedings of the 13th Asia Pacific Management Conference (Melbourne, VIC).

Marinoni, G., Van't Land, H., and Jensen, T. (2020). The Impact of Covid-19 on Higher Education Around the World. IAU Global Survey Report.

Milkovich, G. T., Newman, J. M., and Milkovich, C. (1996). Compensation. New York, NY: Irwin Homewood.

Mwita, K. M. (2020). Effects of corona virus pandemic (covid-19) on selected human resource management practices in Tanzania. East Afr. J. Soc. Appl. Sci. 2, $252-260$.

Osibanjo, A. O., Adeniji, A. A., Falola, H. O., and Heirsmac, P. T. (2014). Compensation packages: a strategic tool for employees' performance and retention. Leonardo J. Sci. 65-84.

Pradhan, R. K., and Jena, L. K. (2017). Employee performance at workplace: conceptual model and empirical validation. Bus. Perspect. Res. 5, 69-85. doi: $10.1177 / 2278533716671630$

Purwanto, A., Asbari, M., Fahlevi, M., Mufid, A., Agistiawati, E., Cahyono, Y., et al. (2020). Impact of work from home (WFH) on Indonesian teachers performance during the Covid-19 pandemic: an exploratory study. Int. J. Adv. Sci. Technol. 29, 6235-6244.

Qamar, T. Q., and Bawany, N. Z. (2021). Impact of COVID-19 on higher education in Pakistan: an exploratory study. Int. J. Educ. Res. Innov. 8, 503-518. doi: 10.46661/ijeri.5645

Rahiman, H. U., Frank, R. A., and Kodikal, R. (2018). Impact of human resource practices on faculty commitment: an empirical study. J. Strateg. Hum. Resour. Manage. 7:43.

Rehman, A. U. (2020). Challenges to online education in Pakistan during COVID-19 and the way forward. AIJR Preprints. 241, 503-512. doi: 10.15520/sslej.v6i07.2829

Ripley, D. E. (2002). The Work Environment and Training Effectiveness: An Overlooked Element in Human Resource Manament Instruction. The University of Canterbury, Christchurch.

Shahzad, K., Bashir, S., and Ramay, M. I. (2008). Impact of HR practices on perceived performance of university teachers in Pakistan. Int. Rev. Bus. Res. Pap. 4, 302-315.
Shahzad, M., Qu, Y., Zafar, A. U., Rehman, S. U., and Islam, T. (2020). Exploring the influence of knowledge management process on corporate sustainable performance through green innovation. J. Knowl. Manage. 24, 2079-2106. doi: 10.1108/JKM-11-2019-0624

Shahzadi, I., Javed, A., Pirzada, S. S., Nasreen, S., and Khanam, F. (2014). Impact of employee motivation on employee performance. Eur. J. Bus. Manage. 6, 159-166.

Sheikh, Z., Islam, T., Rana, S., Hameed, Z., and Saeed, U. (2017). Acceptance of social commerce framework in Saudi Arabia. Telemat. Inform. 34, 1693-1708. doi: 10.1016/j.tele.2017.08.003

Singh, K. (2004). Impact of HR practices on perceived firm performance in India. Asia Pacific J. Hum. Resour. 42, 301-317. doi: 10.1177/1038411104048170

Skinner, B. F. (1958). Reinforcement today. Am. Psychol. 13:94. doi: $10.1037 /$ h0049039

Stavrou-Costea, E. (2005). The challenges of human resource management towards organizational effectiveness: a comparative study in Southern EU. J. Eur. Industr. Train. 29, 112-134. doi: 10.1108/03090590510585082

Terpstra, D. E., and Rozell, E. J. (1993). The relationship of staffing practices to organizational level measures of performance. Pers. Psychol. 46, 27-48. doi: 10.1111/j.1744-6570.1993.tb00866.x

Valenzi, E., and Dessler, G. (1978). Relationships of leader behavior, subordinate role ambiguity and subordinate job satisfaction. Acad. Manage. J. 21, 671-678. doi: $10.2307 / 255707$

Wagner, J. A. III. (1994). Participation's effects on performance and satisfaction: a reconsideration of research evidence. Acad. Manage. Rev. 19, 312-330. doi: 10.5465/amr.1994.9410210753

Conflict of Interest: The authors declare that the research was conducted in the absence of any commercial or financial relationships that could be construed as a potential conflict of interest.

Publisher's Note: All claims expressed in this article are solely those of the authors and do not necessarily represent those of their affiliated organizations, or those of the publisher, the editors and the reviewers. Any product that may be evaluated in this article, or claim that may be made by its manufacturer, is not guaranteed or endorsed by the publisher.

Copyright (c) 2021 Irshad, Umar, Rehmani, Khokhar, Anwar, Qaiser and Naveed. This is an open-access article distributed under the terms of the Creative Commons Attribution License (CC BY). The use, distribution or reproduction in other forums is permitted, provided the original author(s) and the copyright owner(s) are credited and that the original publication in this journal is cited, in accordance with accepted academic practice. No use, distribution or reproduction is permitted which does not comply with these terms. 